This work was supported by a grant from the Yugoslav Foundation for Scientific Research.

Branislav D. JankoviC

Muroslav Draškoci

Miomir JaNJić

Microbiological Institute, Faculty of Pharmacy, and Immunology Unit,

Institute for Biological Research, University of Belgrade, Yugoslavia.

${ }^{1}$ Chase, M. W., in Allergic Encephalomyelitis, edit. by Kies, M. W., and Alvord, E. C., 348 (Charles C. Thomas, Springfield, 1959)

${ }^{2}$ Waksman, B. H., Experimental Allergic Encephalomyelitis and the 'A utoAllergic' Diseases (S. Karger, Basel, 1959).

seldberg, W., and Sherwood, S. L., J. Physiol., 120, 3P (1953).

4 Bornstein, M. B., and Appel, S. H., J. Neuropath. Exp. Neurol., 20, 141 (1961). Appel, S. H., and Bornstein, M. B., J. Exp. Med., 119, 303 (1964) s Sherwin, A. L., I ichter, M., Cosgrove, J. B., and . ose, B., Science, 134, 1370 (1.961).

6 Paterson, P. Y., and Harwin, S. M., J. Exp. Med., 117, 755 (1963).

${ }^{7}$ Hurst, E. W.. J. Neurol. Neurosurg. Psychiat., 18, 174, 260 (1955).

\section{Effect of Trypsin Inhibitor isolated from Sows' Colostrum on the Absorption of $\gamma$-Globulin by Piglets}

It is generally held that the absorption of whole proteins by piglets occurs only during the first two days of life. By this mechanism the baby pig acquires antibodies. For the first 5 days post partum the sow's colostrum contains a trypsin inhibitor ${ }^{1}$ and it has been suggested ${ }^{2}$ that the function of the trypsin inhibitor is to prevent the digestion of $\gamma$-globulins, so allowing the piglet to absorb them intact. Extending this theory further, it can be postulated that whole protein absorption ceases when there is insufficient inhibitor in the colostrum to inactivate all the trypsin entering the gut.

We prepared a solution of trypsin inhibitor from sow's colostrum according to the method of Laskowski et al. ${ }^{1}$. The potency of the solution expressed in the units of Kunitz $^{3}$ was $200 \times 10^{3} \mathrm{ml}$. Each ml. of solution was capable of inactivating $30 \mathrm{mg}$ of the sample of crystalline trypsin used in the assay. Sow's colostrum was chosen as starting material as it was thought that the inhibitor it contained could well be more effective in vivo than either the soya bean or bovine colostrum proteins used by earlier workers ${ }^{4,5}$. Laskowski et al. ${ }^{1}$ have demonstrated important differences in the properties of inhibitors isolated from these sources that show them to be different substances, so it seemed advisable to use the native protein.

Samples of $\gamma$-globulin were prepared by a combination of sodium sulphate precipitation and fractionation on $a$ DEAE cellulose column from pig serum. The $\gamma$-globulin was labelled with iodine-131 by the method of McFarlane ${ }^{6}$.

Quantitative portions of labelled $\gamma$-globulin were given to two piglets in a litter of eight, $2 \mathrm{~h}$ after birth. Blood samples were taken $12 \mathrm{~h}$ later and the serum volumes of the piglets were estimated. Calculation showed that about 13 per cent of the activity administered was present in the serum protein.

The remaining six piglets were given a single dose of labelled $\gamma$-globulin at $60 \mathrm{~h}$ of age. Blood samples were taken $12 \mathrm{~h}$ later and serum volumes were calculated. With one exception, only negligible amounts $(0.3-0.9$ per cent) of activity were present in the serum proteins. One piglet still absorbed much $\gamma$-globulin (11 per cent in serum protein). This animal was discarded. The five remaining piglets were divided into an experimental group of three animals, each of which received $4 \mathrm{ml}$. trypsin inhibitor each hour from $74 \mathrm{~h}$ onwards, and a control group of two animals, given $4 \mathrm{ml}$. of distilled water each hour. At $80 \mathrm{~h}$, all five animals received a second dose of labelled $\gamma$ globulin, accompanied by trypsin inhibitor or water. Dosing with trypsin inhibitor or water continued for a further $12 \mathrm{~h}$ ( $92 \mathrm{~h}$ of age), when blood samples were taken and serum volumes estimated. During the 18 -h period
(74-92 $\mathrm{h}$ of age) each piglet in the experimental group received inhibitor equivalent to at least 11 . of colostrum ${ }^{1}$. There was no increase in either group in the quantity of labelled $\gamma$-globulin detectable in the precipitated serum protein fraction.

This result indicated that this inhibitor is incapable of inducing the absorption of $\gamma$-globulin in 3 -day-old piglets. It would seem that the disappearance of trypsin inhibitor from colostrum does not account for the cessation of absorption of $\gamma$-globulin.

We thank Dr. W. A. Hemmings for preparing the labelled $\gamma$-globulin and the Pig Industry Development Authority for financial assistance.

A. G. Chamberlain

G. C. Perry

Departmont of Agriculture, University College of North Wales, Bangor.

R. E. JONES

Agricultural Research Council Unit of Embryology,

Department of Zoology, Bangor.

' Laskowski, M., Kassell, B., and Hagerty, G., Biochim. Biophys. Acta, 24, $300(1957)$.

${ }^{2}$ Laskowski, jun., M., and Laskowski, M., J. Biol. Chem., 190, 563 (1951),

3 Kunitz, M., J. Gen. Physiol., 30, 291 (1947).

${ }^{4}$ Barrick, E. R., Matrone, G., and Osborne, J. C., Proc. Soc. Exp. Biol. and Med., 87, 92 (1954).

${ }^{5}$ Nordbring, F., and Olsson, B., Acta Soc. Med. Upsal., 63, 25 (1958).

- McFarlane, A. S., Biochem. J., 62, 135 (1956).

\section{Spontaneous Occurrence of Autoantibodies Cytotoxic to Thymus Cells in the Sera of Mice of the 129 Strain}

Autoantibodies of various types appear in the serum during autoimmune diseases; but it is not clear whether they are the cause or the result of the pathological process. Grabar $^{1}$ and Boyden ${ }^{2}$ have postulated that autoantibodies are constantly present in low concentrations in the normal organism, their function being to transport normal catabolic products. This possibility that autoantibodies may have a physiological function was strengthened by the recent detection of autoantibodies in normal human sera $^{3,4}$ and in sera of healthy mice ${ }^{5}$. In the work recorded here, sera of normal adult mice of the 129 inbred strain were found to be cytotoxic for thymus cells of mice of strain 129 and of other strains in the presence of guineapig serum. Although the nature of the factor in 129 strain mouse serum has not yet been fully established, its behaviour in the cytotoxic test is similar to that of welldefined isoantibodies ${ }^{6,7}$. It will therefore be referred to here as an antibody.

Mice of an inbred $129 / R r$ colony maintained at New York University Medical School by Dr. E. A. Boyse were used as donors of sera in most experiments. In some experiments the tests were performed with the sera of 129 mice reared in other laboratories $(129 / J$ from the Jackson Memorial Laboratory, Bar Harbor, Maine, and 129/Rr from the Immunogenetics Research Unit, Duke University Medical Center, Durham, North Carolina, from which the New York University colony originated). The mice were bled either from the tail or from the retro-orbital sinus. The sera were separated within $5 \mathrm{~h}$ after bleeding and were stored at $-10^{\circ} \mathrm{C}$. The cytotoxic test was a modification ${ }^{8}$ of the method of Gorer and O'Gorman'. The guinea-pig serum used as a source of complement was absorbed with washed packed leukaemic cells until all cytotoxic activity against mouse thymus cells ${ }^{10,11}$ had been removed. Cytotoxic titres were defined as the highest dilution of serum at which 50 per cent of the cells were killed.

The sera of all 129 mice 5 weeks of age or older contained an antibody which in the presence of guinea-pig com- 